IZA DP No. 5237

Immigrant Networks and the U.S. Bilateral Trade:

The Role of Immigrant Income

Kusum Mundra

October 2010 


\title{
Immigrant Networks and U.S. Bilateral Trade: The Role of Immigrant Income
}

\author{
Kusum Mundra \\ Rutgers University \\ and IZA \\ Discussion Paper No. 5237 \\ October 2010 \\ IZA \\ P.O. Box 7240 \\ 53072 Bonn \\ Germany \\ Phone: +49-228-3894-0 \\ Fax: +49-228-3894-180 \\ E-mail: iza@iza.org
}

Any opinions expressed here are those of the author(s) and not those of IZA. Research published in this series may include views on policy, but the institute itself takes no institutional policy positions.

The Institute for the Study of Labor (IZA) in Bonn is a local and virtual international research center and a place of communication between science, politics and business. IZA is an independent nonprofit organization supported by Deutsche Post Foundation. The center is associated with the University of Bonn and offers a stimulating research environment through its international network, workshops and conferences, data service, project support, research visits and doctoral program. IZA engages in (i) original and internationally competitive research in all fields of labor economics, (ii) development of policy concepts, and (iii) dissemination of research results and concepts to the interested public.

IZA Discussion Papers often represent preliminary work and are circulated to encourage discussion. Citation of such a paper should account for its provisional character. A revised version may be available directly from the author. 


\section{ABSTRACT \\ Immigrant Networks and U.S. Bilateral Trade: The Role of Immigrant Income*}

This paper examines the role of immigrant networks on trade, particularly through the demand effect. First, we examine the effect of immigration on trade when the immigrants consume more of the goods that are abundant in their home country than the natives in a standard Heckscher-Ohlin model and find that the effect of immigration on trade is a priori indeterminate. Our econometric gravity model consists of 63 major trading and immigrant sending countries for the U.S. over 1991-2000. We find that the immigrants' income, mostly through the demand effect, has a significant negative effect on U.S. imports. However, if we include the effect of the immigrant income interacted with the size of the immigrant network, measured by the immigrant stock, we find that the higher the immigrant income the lower is the immigrant network effect for both U.S. exports and imports. This we find in addition to the immigrant stock elasticity of $0.27 \%$ for U.S. exports and $0.48 \%$ for U.S. imports. Capturing the immigrant assimilation with the level of immigrant income, this paper finds that the immigrant network effect on trade flows is weakened by the increasing level of immigrant assimilation.

JEL Classification: F22, F11, J10

Keywords: immigrant networks, immigrant assimilation, demand effect, trade

Corresponding author:

Kusum Mundra

Department of Economics

Rutgers University

Newark, NJ 07901

USA

E-mail: kmundra@andromeda.rutgers.edu

* An earlier version of section 2 has benefitted from discussion with Prasanta Pattanaik. 


\section{Introduction}

Beginning from the work by Gould (1994) there is increasing literature examining the effect of immigrant networks on trade with the immigrants' home country. There is increasing empirical evidence that the immigrant population, particularly the stock of immigrants living in a country, provides the social and coethnic networks that facilitate trade with their home country by removing some informal trade barriers and lowering transactions cost to trade. ${ }^{1}$ The literature has found that the immigrants (or immigrant based networks) have a positive effect on the bilateral trade for the U.S. (Gould 1994; Dunlevy and Hutchinson 1999; Dunlevy 2004; Rauch 1999; Herander and Saavedra 2005; Bandyopadhyay 2008) and for Canada (Head and Reis 1998). Immigrants "home-link" increases trade with their home countries through the immigrants' home country information (information effect) and through their demand for goods from their home country (demand effect). In the previous literature both the immigrant information and the demand effect is measured by the size of the immigrant stock. In this paper, in addition to the size of the immigrant stock measuring

\footnotetext{
${ }^{1}$ In international trade Trefler (1995) has found a strong evidence of coethnic and social networks in explaining the missing trade links and Grief (1993) and Rauch and Casella (1998) have shown that business and social networks help in alleviating informal trade barriers.
} 
immigrants' effect on trade we explore the role of immigrants' income on the bilateral trade, particularly through the immigrants' demand effect.

Immigrants carry home-country information that helps in matching buyers and sellers and enforcement of trading contacts (information effect). Immigrants have information on different traders and the type of goods available both in the U. S. and their home countries. This knowledge helps in promoting bilateral trade between the host and the home country. In addition, immigrants' information on the legal set up in their country of origin, familiarity with the home-country language, and knowledge of how business is conducted in their home country helps in enforcing trading contacts with their home country. Immigrants also demand goods from their home country increasing their home country exports to the host country - demand effect. ${ }^{2}$ Light et al.(2002), while exploring the effect of English speaking immigrants on export claims that immigrant entrepreneurs import familiar goods from their home countries since there is a demand for these goods in their host country.

This paper examines the demand effect of the immigrants, particularly the effect of immigrants' income on trade. In the literature there is no explicit attempt to

\footnotetext{
${ }^{2}$ There is an extensive literature on the role played by immigrants demand for goods from their home country in generating and sustaining immigrant entrepreneurship. For a good discussion on immigrants demand and growth of ethnic business enclaves see Portes and Rumbaut (1996), Light and Bonacich (1988), and Halter (1995) to name a few.
} 
distinguish the immigrants' information effect from their demand effect and hence there are conflicting and different findings regarding the effect of immigrants' information and demand on trade (Wagner et al. 2002). Head and Reis (1999) find that the immigrant elasticity for imports is three times of that of the exports and they argue that if the information effect for both exports and imports is assumed to be of equal magnitude, then the demand effect of immigrants has to be twice that of their information effect. However, Girma and Yu (2002) and Gould (1994) find higher immigrant elasticity for exports than for the U.S. imports. In this paper we include immigrants' income in the U. S. as a proxy for immigrants' level of assimilation and purchasing power and estimate the effect of the immigrant demand on trade after controlling for the size of the immigrant network.

Immigrants' demand and its effect on the global economy is understudied. Typically, when labor is mobile across countries, it is assumed that migration changes the labor supply of the host and the home country. While the effect of migration on the labor supply is crucial, there are other important effects of migration, in particular on the demand side that are neglected both in the migration and in the trade literature and deserve further exploration. In the majority of international trade models goods mobility is analyzed assuming consumers in the two trading partners (or multi trading partners) have identical demand patterns. ${ }^{3}$ With increasing migration around

\footnotetext{
${ }^{3}$ It is generally assumed that both migrants and natives have identical and homothetic demand.
} 
the world the immigrants demand for different type of goods will be significant and may have important effects on the terms of trade and trade flows.

The relationship between trade and immigration, whether they are substitutes or complements, is also an important question for bilateral trade agreements and immigration policy. It is often assumed that the goods and the labor flows are substitutes, as was the case with NAFTA. It was expected that relatively freer trade between Mexico and the U.S. may raise Mexican wages and eventually lower the immigration from Mexico to the U.S. (also possibly undocumented migration) - making trade and labor flows substitutes. However, Martin(2005) show that there is an evidence of increased migration post NAFTA from Mexico to the U.S. and thus post NAFTA trade and migration were complements instead of substitutes. Different demand patterns of immigrants from natives may have a significant effect on the trade between the sending and the receiving country of the immigrants.

In this paper, in addition to the empirical investigation of the effect of immigrant income on trade, we also examine the effect of immigrants' different demand from natives on the trade between the immigrants' host and their home country in the widely used two input-two good standard Heckscher-Ohlin(H-O) model. We distinguish between the immigrants and the natives on the basis of their demand patterns and assume that the immigrants on an average consume more of the goods that are available in abundance in their home countries than the natives. For instance, food is an example where immigrants and natives have different demand patterns. Immi- 
grants demand food from their home countries and there are studies identifying that food choices are determined by individual, cultural, social, economical and historical factors as in Fischler (1988) and Capella (1993).

The paper is organized as follows. In Section 2 we discuss the simple H-O model used in this paper with different demand for immigrants and natives and section 3 talks about the effect of immigrant income on trade through their demand effect. Section 4 presents the empirical model and we conclude in section 5 .

\section{Immigrant and the Heckscher-Ohlin Model}

In this section we explore the effect of immigration on the terms of trade between the country of origin $(\mathrm{H})$ of the immigrants and the country of settlement $(\mathrm{F})$, if the immigrants and natives have different demand patterns, in the most extensively used $\mathrm{H}-\mathrm{O}$ trade model. We assume that immigrants on an average demand and consume more goods from their home country than the natives and because of tariffs and other trade barriers, the relative prices of the final goods and hence the factor prices are different in the two countries. At the pre-migration terms of trade immigrants in the host country will have a different level of income and will be faced with different product prices. Therefore, at the terms of trade that prevailed in the equilibrium before immigration the aggregate world demand for commodities can change. This 
change on the demand side together with the change on the production side from changes in factor supplies in the two countries due to immigration can lead to changes in the terms of trade. In our simple $\mathrm{H}-\mathrm{O}$ model there are two countries, $\mathrm{H}$ (the immigrants country of origin or the home country) and F (the immigrants' host country or the foreign country), $i=\mathrm{H}$ and $\mathrm{F}$. There are two goods, $\mathrm{A}$ and $\mathrm{B}$, produced in both the countries, $j=\mathrm{A}$ and $\mathrm{B}$. There are two factors of production (Labor $\mathrm{L}$ and capital K). $L_{j}^{i}$ is the amount of labor employed in sector $j$ in country $i ; K_{j}^{i}$ is the amount of capital employed in sector $j$ in country $i ; w^{i}$ is the wage rate in country $i ; a_{L j}^{i}$ and $a_{K j}^{i}$ are respectivelythe labor-output ratio and the capital-output ratio in sector $j$ in country $i$; and $D_{j}^{i}$ is the demand for good $j$ in country $i$.

\subsection{Assumptions}

(A2.1) A is labor intensive and B is capital intensive, i.e., for every faced price ratio $(w / r)=\omega,\left(a_{L A} / a_{K A}\right)>\left(a_{L B} / a_{K B}\right)$

(A2.2) There is constant returns to scale in both the sectors A and B with positive and diminishing marginal productivity

(A2.3) Country $\mathrm{H}$ is labor abundant and country $\mathrm{F}$ is capital abundant, $(K / L)^{H}<$ $(K / L)^{F}$

(A2.4) Individuals and firms are price takers

(A2.5) Country F imposes a small tariff at a rate $t$ on its imports

(A2.6) Capital is owned equally in both the countries and is not mobile across 
countries

(A2.7) Each individual in country $\mathrm{H}$ has a continuous locally non-satiated, strictly quasi-concave utility function $\mathrm{U}($.$) and the individual utility function in country \mathrm{F}$ is given by $\mathrm{V}($.$) . At any given prices and income level people in country \mathrm{H}$ buy more of good A and less of good B than people in country F. ${ }^{4}$

From assumption (A2.2) it follows that $a_{L j}^{i}=a_{L j}^{i}(\omega)$ and $a_{K j}^{i}=a_{K j}^{i}(\omega)$. The requirement of full employment of labor is, $a_{L A}^{i} A^{i}+a_{L B}^{i} B^{i}=L^{i}$ and for capital is $a_{K A}^{i} A^{i}+a_{K B}^{i} B^{i}=K^{i}$. Unit cost in each industry is equal to the market price: $a_{L j}^{i} w^{i}+a_{K j}^{i} r^{i}=p_{j}^{i}$. Assume that country $\mathrm{F}$ imports $\mathrm{A}$ and country $\mathrm{H}$ imports B. Let B be numeraire, so that $p_{B}=1$. Let the world equilibrium price ratio be $p^{*}=p_{A}^{*}$. From $(\mathrm{A} 2.5)$ it follows that $\stackrel{* F}{p_{A}}=(1+t) \stackrel{*}{p}$ where $p^{* F}={ }_{p_{A}^{F}}^{*}, p^{* H}=\left(p_{A}^{* H} / p_{B}^{* F}\right)$ and $p_{B}^{* F}=p_{B}^{* H}$; this makes $\left(w^{* H} / r^{* H}\right)<\left(w^{* F} / r^{* F}\right)$ where $w^{* H}<w^{* F}$ and $r^{* H}>r^{* F}$. The higher wages in country $\mathrm{F}$ is an incentive for people to migrate from country $\mathrm{H}$ to F. Assumption (A2.6) would be cleared in the next section.

\subsection{Analysis}

Utility maximization subject to the budget constraint gives the demand function for good $\mathrm{A}$ and good $\mathrm{B}$ in country $\mathrm{H}$ as $D_{A}^{H}\left(p^{H}, y^{H}\right)$ and $D_{B}^{H}\left(p^{H}, y^{H}\right)$, similarly in country $\mathrm{F}$ the demand function is $D_{A}^{F}\left(p^{F}, y^{F}\right)$ and $D_{B}^{F}\left(p^{F}, y^{F}\right)$, where $y^{i}$ is the individual income in country $i$. Let us assume $m n^{H}$ proportion of the world population

\footnotetext{
${ }^{4}$ We assume that there is no demand reversal.
} 
move from country $\mathrm{H}$ to country $\mathrm{F}$, where $n^{H}=L^{H} /\left(L^{H}+L^{F}\right){ }^{5}$ At unchanged equilibrium price $p^{*}$ migration affects world excess demand for good A through the following channels:

(1) Effect on the production of the host country: The increase of labor supply in country $\mathrm{F}$ (by $d L^{H}$ ) increases the production of good A at unchanged equilibrium price, by $d A^{F}=\left(a_{K B}^{* F} / \alpha^{* F}\right) d L^{H}$, say $X$ (see Appendix).

(2) Effect on the production of the home country: The fall in the labor supply of country $\mathrm{F}$ (by $d L^{H}$ ) due to migration, lowers the production of good A by $d A^{H}=$ $-\left(a_{K B}^{* H} / \alpha^{* H}\right) d L^{H}$, say $Y$ ( see Appendix).

(3) Effect on the demand of immigrants:

(3a) Price Effect: The immigrants face a higher price in country $\mathrm{F}$ at the unchanged equilibrium price and this lowers their demand for good A by $m n^{H} D_{A p}^{H}(y, p) d p$, say $T$. Where $d p=p^{*} t$ is the change in price for good A in terms of good $\mathrm{B}$ faced by the immigrants when they move from country $\mathrm{H}$ to country $\mathrm{F}$ and $D_{A p}^{H}($.$) is the$ partial change in the demand for good A due to the price change.

(3b) Income Effect: The immigrants lose their income out of capital and gain income in the form of higher wages they earn in country F, it can be said that the net effect on the income is positive otherwise the immigrants have no incentive to move to the host country. The immigrants leave their capital $\left(m n^{H} K^{H}\right)$ behind and thus the

\footnotetext{
${ }^{5}$ This assumption is harmless since in most of the countries migration and immigration is controlled by the government.
} 
change in the income of the immigrants due to the loss of rental income on the capital is $m n^{H} r^{H}\left(K^{H} / L^{H}\right)$ and this lowers the demand for good A by $m n^{H} r^{H}\left(K^{H} / L^{H}\right) D_{A y}^{H}$. The higher wage earned by the immigrants is given by $\left(w^{F}-w^{H}\right)=d w$ (see Appendix). The effect on the demand for good $\mathrm{A}$ is given by $m n^{H} D_{A y}^{H} d w$, say $F$.

(4) Effect on the demand of the population in country $H$ who do not migrate: The capital left behind by the immigrants is enjoyed by the natives of country $\mathrm{H}$ and their rental income goes up by $(1-m) n^{H} r^{H}\left[\left(K^{H} /(1-m) * L^{H}\right)-\left(K^{H} / L^{H}\right)\right]$, this in turn increases their demand for good A by $(1-m) n^{H} r^{H}\left[\left(K^{H} /(1-m) * L^{H}\right)-\left(K^{H} / L^{H}\right)\right] D_{A y}^{H}$, say $S$. This distribution of income assumes that there is an equal distribution of capital among the population, assumption (A2.6).

With the world prices held fixed at the initial equilibrium level the change in the excess demand can be written as

$$
\begin{aligned}
= & X+Y+T+F+S \\
= & d A^{F}-d A^{H}+m n^{H} D_{A p}^{H}(y, p) d p+m n^{H} D_{A y}^{H} d w+ \\
& (1-m) n^{H} r^{H}\left[\left(K^{H} /(1-m) * L^{H}\right)-\left(K^{H} / L^{H}\right)\right] D_{A y}^{H} \\
= & m n^{H}\left[\left(D_{A y}^{H} d w+D_{A p}^{H} d p\right)+\left(a_{K B}^{* F} / \alpha^{* F}-a_{K B}^{* H} / \alpha^{* H}\right)\right]
\end{aligned}
$$

In the present analysis the change in the excess demand given by (1) is a priori ambigous. The effect of immigration on the terms of trade is indeterminate and the indeterminacy in this analysis comes from the demand side combined with the 
production side. The change in demand owing to a price change and the change in the demand owing to the change in wages work in opposite directions, therefore, the excess demand change for good A at the unchanged world price can go up, remain unchanged or go down after immigration from one country to another. If the excess demand for good A goes up after immigration from country $\mathrm{H}$ to country $\mathrm{F}$, then the world prices for good A must go up, moving the terms of trade in favor of country H. But if the excess demand for good A after immigration falls then the terms of trade would move against country $\mathrm{H}$. Thus this further makes a case for an empirical examination of the effect of immigration on trade.

\subsection{Sufficient Condition}

Given our assumption that stability conditions hold in the international market at the initial equilibrium prices $p^{*}$, if immigration increases the excess demand for good A, then the terms of trade will move in favor of good A. However, we have already shown that when both goods are normal at $p^{*}$, immigration will increase the demand for both goods. Therefore, it is clear that if, at $p^{*}$, immigration reduces the production of $\mathrm{A}$ in country $\mathrm{H}$ more than it increases the production of $\mathrm{A}$ in country $\mathrm{F}$, then the terms of trade will move in favor of A. At fixed $p^{*},(L / K)_{A}^{F}$ and $(L / K)_{A}^{H}$ are fixed, therefore a sufficient condition for the terms of trade to move in favor of good A (at the initial or before immigration prices and wages) is that the fall in the production of good $\mathrm{A}$ in the country $\mathrm{H}$ exceeds the increase in the production of good $\mathrm{A}$ in country 
F. This implies:

$$
d K_{A}^{F} \psi(L / K)_{A}^{F}<d K_{A}^{H} \psi(L / K)_{A}^{H}
$$

where, $\psi(l L / K)$ is the average product of capital written as a function of $L / K$. After substituting for the change in the amount of capital employed in sector A of country F after migration at $p^{*}$, given by $d K_{A}^{F}=d L^{F} /\left\{(L / K)_{A}^{F}-(L / K)_{B}^{F}\right\}$ and $d K_{A}^{H}=d L^{H} /\left\{(L / K)_{A}^{H}-(L / K)_{B}^{H}\right\}$ in (2) we get

$$
\left[\left|d L^{F}\right| /\left\{(L / K)_{A}^{F}-(L / K)_{B}^{F}\right\}\right] \psi(L / K)_{A}^{F}<\left[\left|d L^{H}\right| /\left\{(L / K)_{A}^{H}-(L / K)_{B}^{H}\right\}\right] \psi(L / K)_{A}^{H}
$$

At the initial equilibrium, $\psi(L / K)_{A}^{F}<\psi(L / K)_{A}^{H}$ and $d L^{F}=-d L^{H}$, Thus (3) holds if

$$
\left[(L / K)_{A}^{F}-(L / K)_{B}^{F}\right] \geq\left[(L / K)_{A}^{H}-(L / K)_{B}^{H}\right]
$$

After some manipulation (4) becomes:

$$
E_{B}(L / K)_{B}^{H} /\left(\omega^{H}\left(\omega^{F}-\omega^{H}\right)\right) \leq E_{A}(L / K)_{A}^{H} /\left(\omega^{H}\left(\omega^{F}-\omega^{H}\right)\right)
$$

where $E_{A}$ and $E_{B}$ are the elasticities of factor substitution in sectors $\mathrm{A}$ and $\mathrm{B}$. The inequality in (5) holds iff

$$
E_{A} / E_{B} \geq(L / K)_{B}^{H} /(L / K)_{A}^{H}
$$

However, the RHS of (6) is always less than 1 because good A is more labor intensive than good B. Hence, if $E_{A} \geq E_{B}$, then (2) will necessarily hold and the terms of trade 
move in favor of good A. Similarly it can be shown that when $E_{B}>E_{A}$, then the terms of trade move in the favor of good B.

\section{Immigrants' Income and Demand}

In the previous studies the findings on the effect of immigrants on trade are puzzling, particularly because the two channels of immigrant links, immigrant information effect and the immigrants demand effect, are not distinguished and immigrant stock is a proxy for both the effects. In this paper we attempt to distinguish between the immigrant "information effect" and the "demand or preference effect" by including immigrant stock (measuring the size of the immigrant network) as well as the immigrant income levels from various U.S. trading partners. Immigrants demand goods from their home country and this increases the U.S. imports from their home country. For example, Indian immigrants demand spices from India and gradually there are Indian immigrants in the U. S. as well as traders of non-Indian origin involved in spice trade with India. It is recognized that this will have a positive effect on the U. S. imports and will not affect U. S. exports. Immigrants' income will significantly affect their demand for goods from their home country, in turn affecting more U.S. imports than exports. If the home country goods are more costly in the U.S. than some local cheaper substitutes, the demand for home country goods will increase as immigrants' income rises. However, if the goods from immigrants home country are 
inferior, higher is the immigrants' income lower will be their demand for these goods.

Immigrants demand for goods from their home country via their income will also depend on the immigrant's enclave and assimilation in the U.S. Immigrant income levels are strongly correlated with the levels of education and past studies have shown that education levels are important in determining the degree of immigrant assimilation in the U. S. (Borjas 1995, Greenwood and McDowell 1986). The literature on the immigrants assimilation in the U.S. have found evidence that immigrants assimilation not only depends s on their education levels but also on the number of immigrants from their home country living in the U.S (Borjas 1995; Chiswick 1984). Chiswick and Miller (1996, 2002) measuring immigrants' social networks by the extent of linguistic concentration in the area where the immigrant resides find that higher the immigrant network lower is immigrants' incentive to learn English and hence lower is their assimilation into the host society.

Immigrants with a large immigrant enclave will maintain their strong demand for home country goods, but will also have all the resources required to invest in import substitution activities. Dunlevy and Huthinson (1999) find that immigrants lower imports from New Europe, and the reason being that the new immigrants do not have enough time in the U. S to use the home-country information they carry. But they also argue that the falling pro trade effect of immigrants over time is explained by the argument that the immigrants are becoming Americanized and their "demand effect" is falling. Again food is an excellent example here. We do find that the 
extensive varieties of salsa and Mexican hot sauce production in the U.S. is due to the large Mexican immigrants. With increasing immigrants from Indian subcontinent in the U.S. one finds more and more Indian snacks that were previously imported from India are now produced by local businesses owned by Indian immigrants. All these are examples where immigrants with higher income levels and larger immigrant enclaves are substituting the imports from their home country with the U.S. produced substitutes for ethnic home imports.

In the literature on the effect of immigrant networks on trade it is argued that the immigrant income and demand will have a more significant effect on imports, however immigrants' income might have an indirect effect on the strength of immigrant home link and potentially affecting exports. Larger immigrant stock have a more stronger "home-link" effect. With higher income and more economic assimilation the information effect often captured by immigrant stock might also be getting weaker and thus lowering the immigrant effect on exports. However, there is evidence that there might be a reverse effect with a possibility that over time and with higher upward income mobility in the U.S. immigrants might specialize in the production and exports of goods from the U. S. to their home countries. As immigrants rise up the economic ladder they are in a better position and have more well developed social networks in the U.S. to engage in entrepreneurial activities and opening trade in new channels with their home countries. 


\section{Empirical Model}

The empirical model is based on the 'gravity framework'- where the trade between the U. S. and its trading partners, who are also immigrant-sending countries, is explained by different economic factors in the U. S. and the home countries. It is very well known in empirical trade literature that Gravity Model works well in overall explanation of the trade between countries and is consistent with many trade theories. ${ }^{6}$ We begin our specification with Frankel (1997) basic constant elasticity Gravity model where the trade is proportional to the product of GNP or GDP of the two countries and is inverse to the distance, $D_{i j}$, between the two countries ${ }^{7}$ :

$$
F_{i j}=\frac{Y_{i} Y_{j}}{D_{i j} X_{i j}}
$$

To this multiplicative Gravity model we add product of per capita GNP, which takes into account the diverse stage of development of different countries (Frankel

${ }^{6}$ Helpman (1987) showed that the bilateral trade between countries is proportional to their GDP levels in the differentiated products and increasing returns framework, whereas Deardorff (1998) have tried to reconcile the Gravity models with traditional H-O frameworks.

${ }^{7}$ In a recent paper Disdier and Head (2008) finds that after controlling for different sample and methods used to estimate gravity models the negative impact of distance on trade is robust. 
1995, Rauch 1999). The vector Xij includes factors that assist or hinder trade by influencing the transaction or transportation cost. In addition to the total income capturing the size of the economy and relative income accounting for the similarity between the U. S. and other countries, we include on the lines of Frankel whether U.S. and its trading partners are both English speaking countries.

The gravity model in (7) extends to

$$
F_{U S j}=\left(G N P_{U S} G N P_{j}\right)^{\alpha}\left(P G N P_{U S} P G N P_{j}\right)^{\beta}(\text { Distance })^{-\gamma} e^{-X_{U S j}}
$$

where $F_{U S j}$ is U.S. imports from the home country $j$ and exports to the home country; $G N P_{U S} G N P_{j}$ is the product of the U.S. and the home country GNP;

$P G N P_{U S} P G N P_{j}$ is the product of the per capita GNP of the home country and the U.S.; DISTANCE is the bilateral distance between the home country and the U.S. and

$$
X_{u s j}=\left(\text { English },_{1} \ln \left(\text { IMMSTOCK }_{j U S}, \text { Income }_{j U S}\right)\right.
$$

ENGLISH is a dummy variable measuring whether the immigrant home country is a majority English speaking country, measuring the language similarity with the U.S., IMMSTOCK $K_{U S}$ is the stock of immigrants from country $j$ in the U.S., and $I N C O M E_{j u s}$ is the average income of the immigrants from country $j$ in the U.S. 
With higher income we might expect that the immigrants might be demanding more of the relatively expensive goods from their home country or with higher income there is a possibility that immigrants are more assimilated within the American society and demand less of the ethnic goods ${ }^{8}$ The log gravity model in (7) becomes

$$
\begin{aligned}
\ln F_{U S j}= & \rho+\alpha \ln \left(G N P_{U S} G N P_{j}\right)+\beta \ln \left(P G N P_{U S} P G N P_{j}\right)+\gamma \ln D I S T A N C E_{U S j t} \\
& +\delta E N G L I S H+\eta_{1} \ln (I M M S T O C K)_{j U S}+\eta_{2} I N C O M E_{j U S}+\epsilon_{U S j}
\end{aligned}
$$

We will expect that higher the IMMSTOCK, higher will be the positive effect on trade $\left(\eta_{1}>0\right)$ and if the higher income might have a positive effect on trade $\left(\eta_{2}>0\right)$ or a negative effect on trade $\left(\eta_{2}<0\right)$. To further explore the role of the immigrants assimilation and income on trade we interact the average immigrant income from country $j(I N C O M E)$ with the immigrant stock from country. Thus

$X_{u s j}=\left(\right.$ English $, \ln (I M M S T O C K)_{j U S}, I N C O M E_{j U S}, I N C O M E_{j U S} * \ln (I M M S T O C K)_{j U S}$ and the model in (9) becomes

$$
\begin{aligned}
\ln F_{U S j}= & \rho+\alpha \ln \left(G N P_{U S} G N P_{j}\right)+\beta \ln \left(P G N P_{U S} P G N P_{j}\right)+\gamma \ln D I S T A N C E_{U S j t} \\
& +\delta E N G L I S H+\eta_{1} \ln (I M M S T O C K)_{j U S}+\eta_{2} I N C O M E_{j U S} \\
& +\eta_{3} \ln (I M M S T O C K) * I N C O M E_{j U S}+\epsilon_{U S j}
\end{aligned}
$$

\footnotetext{
${ }^{8}$ This might possibly not hold for ethnic restaurant food.
} 
There is extensive evidence that larger the size of the immigrant enclave less is the immigrants' incentive to assimilate with the natives and potentially less is the immigrant integration into the host society. What does this mean for the immigrant effect on bilateral trade flows? Possibly that higher is the immigrant stock from country $j$, higher is their home effect on trade flows and with rising income and large $I M M S T O C K_{U S}$ greater will be the effect of immigrants on U.S. trade with their home country, particularly U.S. imports $\left(\eta_{3}>0\right)$. However, there is a possibility that with larger share of immigrants from their home country the immigrants might be potentially producing the ethnic goods in the U.S. and substituting their imports with the goods produced in the U.S. In this case we will see that the effect of higher income on the trade flow with the immigrants' home country will be mitigated by the immigrant stock $\left(\eta_{3}<0\right)$. For U.S. exports with rising immigrant income, signifying a higher economic assimilation of the immigrants, makes the immigrant home-link weaker $\left(\eta_{3}<0\right)$.

To further examine the level of income assimilation of immigrants relative to the natives we include the ratio of average immigrant income from country $j$ in the U.S. relative to the average native income $\left(\right.$ PINCOMEUS $\left._{j}\right)$. We estimate the model given by equations (9) and (10) for U.S. exports and imports. 


\subsection{Data}

Our sample consists of 63 countries over $1991-2000 .^{9}$ The list of the countries is given in Appendix A. The U.S. import data is obtained from the extension of the World Trade Database of Statistics Canada, which is a part of the NBER World Trade Database by Feenstra and Lipsey and the nominal GNP and population is from the Penn World tables ${ }^{10}$ Annual data on immigrants across occupation is from the Immigration Statistical Yearbook by the Immigration and Naturalization Services (INS), now called Department of Homeland Security. The data on distance and English language is obtained from the Frankel. ${ }^{11}$ The annual data on average personal income for foreign born from different trading countries is derived from the March Current Population Survey for the years $1994-2000{ }^{12}$

\footnotetext{
${ }^{9} \mathrm{We}$ add El Salvador and Nicaragua and remove Yugoslavia from the sample of countries used in Frankel (1997).

${ }^{10}$ The trade data is downloaded from the Center for International Data at the UC Davis (http://cid.econ.ucdavis.edu.) and the website for the Penn World Tables is http://pwt.econ.upenn.edu.

${ }^{11}$ Distance is from "Direct-Line Distances", International Edition, Gary L. Fitzpatrick and Marilyn J. Modlin, Scarecrow Press, Inc. Metuchen NJ and London 1986.

${ }^{12}$ Foreign born income is missing for 28 countries in 1994 CPS.
} 


\section{Results}

Table 1 gives the results from estimating equation (9) and (10) for the aggregate U.S. exports and imports. From col (1) and (2) we find that immigrant stock has a significant and positive effect on the U.S. bilateral trade flows. A $1 \%$ increase in the immigrant stock increase U.S. exports by $0.27 \%$ and U.S. imports by $0.48 \% .{ }^{13}$ However, we find that a $1 \%$ increase in the average immigrant income level lowers U.S. imports by $0.003 \%$. Thus, higher income levels of the immigrants in the U.S., signifying more assimilation of the immigrants in the U.S., lowers U.S. imports. However, we find a similar significant negative effect of income on both exports and imports when we interact the income level with the size of the immigrant enclave. From cols (3) and (4) we find that a $1 \%$ increase in the income level lowers the U.S. exports and imports by $0.005 \%$. This indicates that higher income coupled with a larger size of the immigrant enclave weakens the effect of immigrant networks on trade flows, both for exports and imports.

In Table 2 we give the results from estimating the effect of average income of immigrants from country $j$ relative to natives, a better measure of immigrant assimilation than simply the average level of immigrant income from country $j$. From col (1) and (2) in Table (2) we find that higher is the PINCOMEUS lower is the effect on U.S. imports. This clearly shows that as the immigrants income levels are closer to

\footnotetext{
${ }^{13}$ This is in line with the previous findings in the literature.
} 
that of the natives or rising above the natives, higher is the immigrant assimilation in the U.S. and lower is their demand for the home country goods. When we interact the level of PINCOMEUS with the level of the immigrant stock, we find that for both the U.S. exports and imports higher PINCOMEUS lowers the trade flows. The fall is higher for U.S. exports (around 0.10\%) than the imports (around 0.9\%).

Other variables are what we expected. $G N P$ and $P G N P$ are all positive and significant. English language dummy have a significant positive effect on both U.S. exports and imports. Distance has a negative significant effect on trade flows.

\section{CONCLUDING REMARKS}

The effect of immigrants' demand in their host country has been neglected when analyzing the effect of immigration. In the literature exploring the effect of immigrants on trade, immigrant stock is a proxy for both the immigrant information effect and the demand effect. In this paper we propose to include the effect of income in the host country U.S. over and above the size of the immigrant stock while examining the effect of immigrant networks on trade. Immigrants relative income to the natives will give us some information on the extent of assimilation of the immigrants in the U.S. and this assimilation will have an important effect on trade flows, a priori more so for imports than exports. 
In this paper we emphasize that immigrants are more than laborers and they have different demand for goods from the natives. We assume that immigrants on an average consume more of the goods that are abundant in their home country in a simple $\mathrm{H}-\mathrm{O}$ model and find that at the terms of trade that prevailed in the equilibrium before immigration, the aggregate world demand for commodities can change. Such a change on the demand side, together with the change on the production side that results from immigration across two countries can lead to changes in the terms of trade.

Our econometric model consists of 63 major U.S. trading partners (who are also big immigrant sending countries) over the time period 1991 - 2000. Our empirical results show that the immigrants income, mostly through demand effect, has a significant negative effect on U.S. imports only. However, if we include the effect of the immigrant income interacted with the size of the immigrant network, measured by the immigrant stock, we find that the income has a negative effect on both the U.S. exports and imports. We find that in addition to the immigrants stock elasticity of $0.27 \%$ for U.S. exports and $0.48 \%$ for U.S. imports, higher income of the immigrants coupled with the large size of the immigrants stock weakens the immigrants network effect with their home country for both the U.S. exports and imports. This we find in addition to the

In this paper we argue that the immigrant network effect on trade flows is weakened by the level of immigrant assimilation. We capture immigrant assimilation 
by their level of income in the U.S. We find a stronger effect of income assimilation on U.S. imports than exports. This paper is an attempt to raise the question that simply looking at the size of the immigrant stock to capture the effect of the immigrant networks on trade might only be a part of the picture, the effect of immigrant assimilation in the host country also needs to be examined in detail while examining the effect of the immigrant networks on trade. 


\section{References}

[1] Bandyopadhyay, S., C. Coughlin, and H. Wall. 2008. "Ethnic Networks and U.D. Exports," Review of International Economics, 16(1):199-213.

[2] Borjas, G. J. "The Economic Benefits from Immigration", Journal of Economic Perspectives Spring 1995, 3-22.

[3] Capella, L. M. and D. R. Arnold. "Acculturation, Ethnic Consumers, and Food Consumption Patterns," Journal of Food Products Marketing 1(4), 1993, 61-79.

[4] Chiswick, Barry R. Illegal Aliens in the United States Labor Market: An Analysis of Occupational Attainment and Earnings." International Migration Review, 1984, 18, pp. 714-32.

[5] Chiswick, Barry R. and Paul W. Miller. "Ethnic Networks and Language Proficiency Among Immigrants." Journal of Population Economics, 1996, 9(1), pp. 19-35.

[6] Chiswick, Barry R. and Paul W. Miller. "Immigrant Earnings: Language skills, linguistic concentrations and the business cycle." Journal of Population Economics, 2002, (15).

[7] Deardorff, A. "Determinants of Bilateral Trade: Does Gravity Work in a Neoclassical World?" in Jeffrey A. Frankel, ed., The Regionalization of the World Economy, University of Chicago Press, 1998, pp. 7-28. 
[8] Disdier, A. and K. Head. "The Puzzling Persistence of the Distance Effect on Bilateral Trade." Review of Economics and Statistics, 2008, 90(1): 37-48.

[9] Dunlevy, J. A. "Interpersonal Networks in International Trade: Evidence on the Role of Immigrants in Promoting Exports from the American States." Review of Economics and Statistics (2004).

[10] Dunlevy, J. A., and W. K. Hutchinson. "The Impact of Immigration on American Import Trade in the Late Nineteenth and early Twentieth Century." The Journal of Economic History 59.4 (1999): 1043-62..

[11] Feenstra, R.C., R.E. Lipsey, D. Haiyan, A.C. Ma, and H. Mo. "World Trade Flows: 1962 - 2000." NBER Working Paper 11040.

[12] Fischler, C. "Food, Self and Identity," Social Science Information 27, 1988, 275292.

[13] Frankel, J. A. 1997. Regional Trading Blocs in the World Economic System. Washington DC: Institute for International Economics, 1997.

[14] Gould, D, M. "Immigrant Links to the Home Country: Empirical Implications for U. S. Bilateral Trade Flows," The Review of Economics and Statistics 76, 1994, 302-316.

[15] Girma, S. and Z. Yu "The Link Between Immigration and Trade: an Evidence from the United Kingdom," Review of World Economics, 138(1), 115-130, 2002. 
[16] Greenwood, M. J. and J. M. McDowell "The Factor Market Consequences of U.S. Immigration," Journal of Economic Literature 24(4), 1986: 1738-1772.

[17] Grief, A. "Contract Enforceability and Economic Institutions in early Trade: The Maghribi Traders' Coalition." American Economic Review 83.3 (1993): 525-548.

[18] Head, K. and J. Reis. "Immigration and Trade Creation: Econometric Evidence from Canada." Canadian Journal of Economics, 31(1), 1998, 47-62.

[19] Helliwell, John F., How Much Do National Borders Matter? (Washington D.C.: Brookings Institution,), 1998.

[20] Helpman, E.. "Imperfect Competition and International Trade: Evidence from Fourteen Industrial Countries, Journal of the Japanese and International Economics, 1987, 1(1): 62-81.

[21] Herander M. G. and L. A. Saavedra. "Exports and the Structure of ImmigrantBased Networks: The Role of Geographical Proximity," The Review of Economics and Statistics 87(2), 2005, 323-335.

[22] Halter, M. "New Migrants in the Marketplace: Boston's Ethnic Entrepreneurs." Editor (Amherst: Univ. of Massacusetts Press, 1995).

[23] Light, I. and E. Bonacich. Immigrant Entrepreneurs: Koreans in Los Angeles (University of California), 1995. 
[24] Light, I., Min Zhou, and Rebecca Kim. "Transnationalism and American Exports in an English-Speaking World." International Migration Review, 36(2002):702725.

[25] Martin, P. "NAFTA and Mexico- US Migration" in NAFTA Revisited, eds G.C. Hufbauer and J. J. Schott, Institute for International Economics, 2005.

[26] Portes, A. and Rumbaut. Immigrant America: A Portrait, 2nd edition, Berkeley CA. Univ. of California Press, 1996.

[27] Rauch, J. E. and Casella, Alessandra. "Overcoming Informational Barriers to International Resource Allocation: Prices and Group Ties," NBER Working Paper no. $6628,1998$.

[28] Rauch, J. E. "Networks versus Markets in International Trade," Journal of International Economics 48, 1996,7-35.

[29] Trefler, D. "Immigrants and Natives in general Equilibrium Models," NBER Working Paper 6209, 1997.

[30] Wagner D., Keith Head, and J. Reis. "Immigration and the Trade of provinces," Scottish Journal of Political Economy, 49(5):507- 525, 2002. 


\subsection{APPENDIX A}

Pre-immigration trade production in both the countries is as follows:

$$
\begin{aligned}
& \stackrel{* i}{A}=\left(1 / \alpha^{* i}\right)\left(L^{i} a_{K B}^{* i}-K^{i} a_{L B}^{* i}\right)=\left[L^{i}\left(k_{B}^{i}-k^{i}\right)\right] /\left[a_{L A}^{i}\left(k_{B}^{i}-k_{A}^{i}\right),\right. \\
& \stackrel{*^{i}}{B}=\left(1 / \alpha^{* i}\right)\left(K^{i} a_{L A}^{* H}-L^{i} a_{K A}^{* i}\right)=\left[L^{i}\left(k_{B}^{i}-k^{i}\right)\right] /\left[a_{L A}^{i}\left(k_{B}^{i}-k_{A}^{i}\right)\right. \\
& \text { where } \stackrel{*^{i}}{\alpha}=a_{L A}^{* H} a_{K B}^{* H}-a_{L B}^{* H} a_{K A}^{* H}, k_{A}^{i}=(K / L)_{A}^{i}, k_{B}^{i}=(K / L)_{B}^{i}, k^{i}=(K / L)^{i}, \text { and } \\
i= & H, F .
\end{aligned}
$$

The wage-rental ratio in both the countries are:

$$
\begin{aligned}
& \omega^{H}=\left(p a_{K B}^{H}-a_{K A}^{H}\right) /\left(a_{L A}^{H}-a_{L B}^{H} p\right)=k_{B}\left(p-\left(a_{K A}^{H} / a_{K B}^{H}\right)\right) /\left(\left(a_{L B}^{H} / a_{L A}^{H}\right)-p\right), \\
& \omega^{F}=\left(p a_{K B}^{F}-a_{K A}^{F}\right) /\left(a_{L A}^{F}-a_{L B}^{F} p\right)=k_{B}\left(p(1+t)-\left(a_{K A}^{F} / a_{K B}^{F}\right)\right) /\left(\left(a_{L B}^{F} / a_{L A}^{F}\right)-p\right)
\end{aligned}
$$

The higher wage income earned by the immigrants is given by:

$$
d w=\left[\alpha^{F}\left(p a_{K B}^{H}-a_{K A}^{H}\right)-\alpha^{H}\left(p(1+t) a_{K B}^{F}-a_{K A}^{F}\right)\right] / \alpha^{F} \alpha^{H}
$$

\subsection{Appendix B}

The 63 trading partners are Algeria, Argentina, Australia, Austria, Belgium, Bolivia, Brazil, Canada, Chile, China, Colombia, Denmark, Ecuador, Egypt, El Salvador, Ethiopia, Finland, France, Ghana, Greece, Hong Kong, Hungary, Iceland, India, Indonesia, Iran, Ireland, Israel, Italy, Japan, Kenya, Kuwait, Libya, Malaysia, 
Mexico, Morocco, Netherlands, New Zealand, Nicaragua, Nigeria, Norway, Pakistan, Paraguay, Peru, Philippines, Poland, Portugal, Saudi Arabia, Singapore, South Africa, South Korea, Spain, Sudan, Sweden, Switzerland, Taiwan, Thailand, Tunisia, Turkey, United Kongdom, Uruguay, Venezuela, Germany. 
Table 1: Log of Export and Import, Immigrant Network and Income

\begin{tabular}{|c|c|c|c|c|}
\hline & U.S. Exports & U.S. Imports & U.S. Exports & U.S. Imports \\
\hline \multirow[t]{2}{*}{$\ln \left(G N P_{U S} G N P_{j}\right)$} & $0.482 * * *$ & $0.588 * * *$ & $0.579^{* * *}$ & $0.688^{* * *}$ \\
\hline & $(0.065)$ & $(0.089)$ & $(0.062)$ & $(0.089)$ \\
\hline \multirow[t]{2}{*}{$\ln \left(P G N P_{U S} P G N P_{j}\right)$} & $0.597 * * *$ & $0.490 * * *$ & $0.600^{* * *}$ & $0.484^{* * *}$ \\
\hline & $(0.084)$ & $(0.114)$ & $(0.079)$ & $(0.110)$ \\
\hline \multirow[t]{2}{*}{$\ln (D I S T A N C E)$} & $-0.311 *$ & $-0.506 * *$ & -0.201 & $-0.397^{*}$ \\
\hline & $(0.158)$ & $(0.219)$ & $(0.149)$ & $(0.213)$ \\
\hline \multirow[t]{2}{*}{ ENGLISH } & $0.682 * * *$ & $0.839 * * *$ & $0.979 * * *$ & $1.142^{* * *}$ \\
\hline & $(0.172)$ & $(0.237)$ & $(0.166)$ & $(0.239)$ \\
\hline \multirow[t]{2}{*}{$\ln (I M M S T O C K)$} & $0.266 * * *$ & $0.4847 * * *$ & $1.068^{* * *}$ & $0.915^{* * *}$ \\
\hline & $(0.070)$ & $(0.0941)$ & $(0.132)$ & $(0.189)$ \\
\hline \multirow[t]{2}{*}{ INCOME } & -0.0001 & $-0.00003 * *$ & $0.0004^{* * *}$ & $0.0004^{* * *}$ \\
\hline & $(8.16 \mathrm{e}-06)$ & $(0.00001)$ & $(0.00007)$ & $(0.00009)$ \\
\hline \multirow[t]{2}{*}{$\operatorname{INCOME} *(\ln I M M S T O C K)$} & & & $-0.00004^{* * *}$ & $-0.00004^{* * *}$ \\
\hline & & & $(5.84 \mathrm{e}-06)$ & $(8.31 \mathrm{e}-06)$ \\
\hline Number of Observations & 325 & 331 & 325 & 331 \\
\hline F-statistic & 50.56 & 27.93 & 56.73 & 28.70 \\
\hline p-value & 0.000 & 0.000 & 0.000 & 0.000 \\
\hline \multicolumn{3}{|c|}{$* * *$ Significant at $1 \% * *$ Significant at $5 \% *$ Significant at $10 \%$} & & \\
\hline
\end{tabular}


Table 2: Log of Export and Import, Immigrant Network and Relative Income

\begin{tabular}{|c|c|c|c|c|}
\hline & U.S. Exports & U.S. Imports & U.S. Exports & U.S. Imports \\
\hline \multirow[t]{2}{*}{$\ln \left(G N P_{U S} G N P_{j}\right)$} & $0.490^{* * *}$ & $0.589^{* * *}$ & $0.615^{* * *}$ & $0.702^{* * *}$ \\
\hline & $(0.064)$ & $(0.089)$ & $(0.061)$ & $(0.090)$ \\
\hline \multirow[t]{2}{*}{$\ln \left(P G N P_{U S} P G N P_{j}\right)$} & $0.602^{* * *}$ & $0.494 * * *$ & $0.589^{* * *}$ & $0.478^{* * *}$ \\
\hline & $(0.084)$ & $(0.114)$ & $(0.077)$ & $(0.111)$ \\
\hline \multirow[t]{2}{*}{$\ln (D I S T A N C E)$} & $-0.308 *$ & $-0.503^{* *}$ & -0.173 & $-0.386^{*}$ \\
\hline & $(0.158)$ & $(0.219)$ & $(0.145)$ & $(0.213)$ \\
\hline \multirow[t]{2}{*}{$E N G L I S H$} & $0.720 * * *$ & $0.839 * * *$ & $0.979^{* * *}$ & $1.142^{* * *}$ \\
\hline & $(0.172)$ & $(0.237)$ & $(0.166)$ & $(0.239)$ \\
\hline \multirow[t]{2}{*}{$\ln (I M M S T O C K)$} & $0.256^{* * *}$ & 0.141 & $1.095^{* * *}$ & $0.984^{* * *}$ \\
\hline & $(0.070)$ & $(0.097)$ & $(0.164)$ & $(0.203)$ \\
\hline \multirow[t]{2}{*}{ PINCOMEUS } & -0.004 & $-0.005 * *$ & $0.095^{* * *}$ & $0.080^{* * *}$ \\
\hline & $(0.002)$ & $(0.002)$ & $(0.012)$ & $(0.018)$ \\
\hline \multirow[t]{2}{*}{$P I N C O M E U S *(\ln I M M S T O C K)$} & & & $-0.009 * * *$ & $-0.008^{* * *}$ \\
\hline & & & $(0.001)$ & $(0.002)$ \\
\hline Number of Observations & 325 & 331 & 325 & 331 \\
\hline F-statistic & 51.59 & 27.99 & 61.97 & 28.64 \\
\hline $\mathrm{p}$-value & 0.000 & 0.000 & 0.000 & 0.000 \\
\hline$* * *$ Significant at $1 \% * *$ Significant at $5 \%$ & ignificant & & & \\
\hline
\end{tabular}

